\title{
IMPACT OF SAVINGS ON CAPITALIZATION: CASE OF SOUTHEAST ASIAN ECONOMIES
}

\author{
Gábor Kutasi $^{1}$, Andrea Lörincz ${ }^{2}$, Eszter Szabó ${ }^{2}$ \\ ${ }^{1}$ National University of Public Service, Budapest, Hungary \\ ${ }^{2}$ Corvinus University of Budapest, Hungary
}

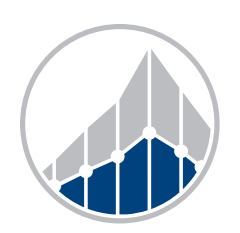

EUROPEAN JOURNAL OF BUSINESS SCIENCE AND TECHNOLOGY

Volume 5 Issue 1

ISSN 2694-7161

www.ejobsat.com

\begin{abstract}
The study analyses the economics intuition that the domestic savings may determine the investments in a country. The assumption is tested on domestic savings between 1982 and 2016 in Southeast Asia economies in a panel regression framework. The hypothesis is that domestic savings stimulate economic growth through investment financing and, thus, the high savings rate observed in Southeast Asian countries can contribute to the outstanding GDP growth in the region. The tests sort out the significant determinants of investments. The analysis successfully indicates the significance of domestic savings beside other variables, and confirms the hypothesis, namely, the domestic savings affect investments and indirectly the economic growth, while FDI does not prove to be significant.
\end{abstract}

\section{KEY WORDS}

savings, investment, Southeast Asia, FDI, economic growth, Feldstein-Horioka puzzle

\section{JEL CODES}

C32, D14, E21, E22, F43

\section{INTRODUCTION}

There is a common approach among the various economics schools that households' saving is an engine of economic growth through investments. According to economic history, catch-up models based on internal savings can result in a more sustainable economic growth path for a national economy. Retail savings represent a secure and predictable source for both the companies and the state. There is a positive correlation assumed between higher household savings rates and investment, although there is a dispute in international literature: higher domestic household savings rates can be coupled with higher investment rates according to Feldstein and Horioka (1980). 
In the following study, the focus is on foreign and domestic savings in several Southeast Asia countries (Singapore, Thailand, Malaysia, China, South Korea, Vietnam and Japan) in the period between 1995 and 2015. The Asian developmental state model has strongly built on the GDP impact of investment and preferred the saving attitude of households to finance the domestic investment. ${ }^{1}$ According to the saving and investment preference of the developmental state model, it is a relevant question whether there is any impact of domestic savings on (next period) investments. The analysis focuses on explaining outstanding values and the comovements. The hypothesis is that domestic savings stimulate economic growth through investment financing and, thus, the high savings rate observed in Southeast Asian countries can contribute to the outstanding GDP growth in the region. The methodology is panel regression analysis on Southeast Asian data. The tests aim to determine the significant determinants of investments in a country. Augmented DickeyFuller test is performed to sort out unit root problem of independent variables. The purpose of analysis is to indicate the significance of domestic savings beside other variables, and this way to prove the hypothesis, namely, the domestic savings affect investments and indirectly the economic growth.

The structure of the study starts with the theoretical framework to support the empirical analysis with economics and empirical tests. It reviews the loanable funds theory as the model describing the relation between the savings and investments, the theory of life cycle hypothesis as a microeconomics modelling on factors of savings which helps to explain the trends in Asian household savings. Besides, the framework gives an outlook about the current approach of Feldstein-Horioka puzzle and the empirical literature about the Asian savinginvestment relation.

The methodological part explains the selection of determinant variables, the composition of the regression function and the sources of data together with some overview on the trends of data. The part about the empirical results explains the multi-steps process of selection of significant determinants of investment and measure the role of domestic household savings in the Southeast Asian case to test the Feldstein-Horioka puzzle. Finally, the discussion compares the current results to the earlier conclusions appearing in the empirical literature review.

\section{THEORETICAL FRAMEWORK}

The relation between savings and investment is described by the loanable funds model where the real interest rate create link between the two flow variables. The model was built on Knut Wicksell's theory which was developed by Bertil Ohlin, Gunnar Myrdal, Jacob Viner and Erik Lindahl. Later, the model got renewed by Hayek as part of neoclassical (neo-Wicksellian) theory, then it was integrated into the newKeynesian IS-LM model by Hicks, as one partial market. From the loanable funds model, mutual lagged determination can be derived between investment and savings. More savings creates bigger pool of sources for investment, and more investment results in bigger disposable income as a base for saving. Focusing on the impact of savings on investment, the loanable funds model helps us to understand that higher volume of domestic savings means higher supply of financing, thus, lower cost of interest payable for debtors/investors who will be willing to raise their investment for lower cost of loans. Even though, more savings means less household (and maybe public) consumption, the economics intuition assumes multiplier effect growing from investment, and this way expects additional economic growth. (Mankiw, 1997; Mátyás, 1980)

But the globalized world economy raises an issue whether is there any growth impact of domestic savings in an internationalized market of loanable funds? The Feldstein-Horioka puzzle

\footnotetext{
${ }^{1}$ The deep institutional explanation of the Asian model is analyzed by Benczes (2002).
} 
gives an empirical reply by assuming that international capital mobility is not perfect, that is why the level of domestic savings can determine the level of domestic investment. Feldstein and Horioka (1980) uncovered in their empirical paper that there is a strong link between the domestic savings rates and domestic investment rates. This means that not the direction of international capital mobility explains the international differences in investment first of all, but the domestic savings since the international differences of savings rate "have resulted in almost equal corresponding difference in the domestic investment rates" among similarly high developed countries. This lead to the second conclusion that actually the capital is not perfectly mobile as it was assumed before by the neoclassical economics.

Tesar (1991) made a robustness check test about the saving-investment linkage, which found significant and well explaining regression function about the correlation for certain group of OECD countries, but uncovered sample bias problem and the challenge of capital control by states. As Bibi and Jalil (2016, pp. 236238) summarized, there are numerous studies which found spurious correlation related to the puzzle or simply found weak link between savings and investments, in other words, strong international capital mobility, meanwhile the authors themselves confirmed the existence of the puzzle with a Common Coefficient Mean Group model. Beyond their literature summary, Fidrmuc (2003, p. 136) recognized that high developed EU countries have financed a high share of their domestic investment from international sources, which phenomenon indicated that the Feldstein-Horioka puzzle has had less importance in the EU with free movement of capital. Baxter and Crucini (1993) uncovered some explanation for the contradictory conclusions. They connected the coexistence of strong saving-investment correlation and high mobility of capital to the investment boom periods on the one hand, and the size of the countries on the other hand.

Attanasio et al. (2000) made a clash of OLS, GMM, Granger Causality and Dynamic Trivariate Model tests on several samples of countries to verify the assumptions among savings, investment and economic growth among others, the hypotheses by Feldstein and Horioka (1980) and Baxter and Crucini (1993). Focusing on impact of savings on investment, their result confirmed the significant impact of savings on investment. Only in case of GMM model, the level of significance did not achieve $5 \%$, but only $10 \%$.

The relationship to the Feldstein-Horioka puzzle in the current study is that it aims to find evidence, first of all, of the strong link between domestic savings and investment. The imperfection of capital mobility in the Southeast Asian region is just the thesis concluded from the puzzle, but not analysed directly.

Savings are influences by decisions made by governments and the corporate and household sector, and the social, economic and demographic characteristics of the household sector. Kapounek et al. (2016) reviews the approach of the so-called lifecycle hypothesis $(\mathrm{LCH})$, which was formulated according to Modigliani (1966) and Sturm (1983). Namely, the lives of individuals are divided into two stages, one active and one inactive. Their savings targets are categorized into four categories by the LCH model: retirement, precautionary reserve, bequest and finally purchase of tangible assets. The model assumes a steady state economy. According to Sturm (1983), the following variables determine the willingness to save the household sector: life expectancy, retirement age, age distribution, family size, average age of employment, skill level. However, the LCH model was questioned by the behavioural economics picture of household preferences (Diamond and Vartiainen, 2007). This conclusion resulted in the behavioural life cycle hypothesis $(\mathrm{BLCH})$.

The outstanding economic performance of Southeast Asian countries has been widely discussed in the literature for a long time. However, there is no consensus on factors of rapid growth experienced in the region. One explanation assumes that the reason of success is the high level of capital accumulation. Namely, these countries prefer savings for future investments to current consumption. While another approach emphasizes the adaptation 
of technologies from developed countries and, this way, the improvement of productivity. Although capital accumulation and productivity growth do not necessarily separate or even strengthen one another in supporting economic growth (Collins and Bosworth, 1996).

The growth model of Collins and Bosworth (1996) allows the release of output-change to factor accumulation and efficiency improvement, and thus can be determined as the source of economic growth. ${ }^{2}$ It was concluded that capital accumulation was remarkable in East Asia, but productivity growth was rather average, thus, the remarkable performance in the region was a result of high level of savings.

There are studies concentrating on interregional capital immobility inward China, which are based on the Feldstein-Horioka approach. On Chinese regional savings and investment, Narayan (2005) executed cointegration test over the period 1952-1998, Li (2010) made OLS and Granger causality tests over the period 1978-2006, and both proved significant savinginvestment relation and low interregional capital mobility, what was connected to government restriction on capital.

Kim (2001) analyses the Asian saving ratio before the financial crisis 1997, when the savings fluctuated between $30 \%$ and $50 \%$ of GDP, which has proved to be a factor in rapid economic development and has contributed to job creation, poverty reduction, productivity growth, trade expansion and increased pros- perity. According to Kim's conclusions, it is worth to stimulate savings as there is a mutual positive relationship between GDP per capita growth and domestic savings rates even in those Asian countries where per capita national income is low.

Liu and $\mathrm{Xu}$ (1997) analysed the case of Shanghai in 1981-1993, and they found strong correlation between the accelerating domestic household savings and a notable shift in importance of investment contributing to the economic growth. They emphasized the role of household savings in investment financing. Their conclusion was that, before the economic reform in 1978, the Chinese government covered the necessary investments from "compulsory savings" and transferred most of the resources to the heavy industry. However, the savings rate has remained high after the reform, with a variety of financial instruments for households.

Tang et al. (2008) investigated the impact of foreign direct and domestic investments on economic growth in China with variable vector autoregressive (VAR) and error correction (ECM) models between 1988 and 2003. Their results show that FDI did not crowded out, but complemented domestic investment, thus supporting economic growth. At the same time, the impact of domestic investment on growth has been much more significant than in case of FDI, and therefore the authors suggest to encouraging domestic savings much more than attracting foreign investment.

\section{METHODOLOGY AND DATA}

The time series will be collated together with additional variables, in panel regression. The main question is whether the investment is significantly influenced by the determinant variables, and besides, whether investment is driven by rather domestic savings or FDI. In addition to the FDI and savings variables analysed in the first half of the study, the following economic indicators were included as the explanatory variables in the model: real interest rate, inflation, GDP growth and government debt. Many previous studies have shown a strong and positive relationship between savings and investment (Feldstein and Horioka, 1980; Bayoumi, 1990, etc.), so the hypothesis in the following analysis will be the same.

In case of FDI, the net inflow data was included in the model. The link between FDI and investment depends on the sector including the foreign investment inflows, and the activity level of domestic enterprises in the sector.

\footnotetext{
${ }^{2}$ The holistic concept of growth potential and structural conditions are analysed in details by Halmai (2015).
} 
If the domestic companies are represented in high number in a certain industry, either the domestic or the foreign capital can suffer from crowding-out independently from the economic policy (İpek and Ayvaz Kızılgöl, 2015). Similar trends can be observed in four ASEAN countries (Vietnam, Malaysia, Thailand and Singapore) and South Korea. Most of the foreign capital flows into the manufacturing industry, the financial services sector and the commercial sector. In China, the preferred sectors of investment are the manufacturing industry and the real estate sector in the largest proportion. Generally, the proportion of domestic investments in the agricultural sector and in the manufacturing is roughly the same as FDI share. In the case of the service sector, however, the former rate is much higher. Thus, the crowding-out effect of FDI does not prevail, and we expect a positive, significant relationship between domestic and foreign investments (ASEAN and UNCTAD, 2017).

To characterize the economic growth of each country, we used the annual percentage growth rate of GDP per capita. Based on Thomas Nixon Carver's and Albert Aftalion's accelerator theory, we expect a positive relationship between output growth rates and domestic investments. According to the theory, if aggregate demand is increasing, companies either increase prices or expand their supply. Companies usually choose the latter option; they are deciding on new investments to increase productivity (Bălăceanu, 2011).

To measure the cost of capital, we introduced the national 12 months real interest rate into the model as an explanatory variable. The literature is very divided about the relationship between real interest rates and investments. McKinnon (1973) and Shaw (1973) argue that the low or negative interest rate will reduce the savings, and thus the investment capital, too (Cho, 1990). Nevertheless, at lower real rates, the cost of capital is lower, which stimulates the investment activity of firms. Namely, a negative relationship between the real interest rate and investments can be assumed.
We expect a negative relationship between sovereign debt and investment, since if government resources are to be spent on debt repayment, less investment can be financed. It is also difficult to reach a clear conclusion on the relationship between inflation and investment. High and unstable inflation is also unfavourable for foreign and domestic investment as it indicates an uncertain macroeconomic environment. Nevertheless, in those countries where inflation is higher, the investors may expect higher risk premia. Higher premium can attract more investment.

The regression equation is the following:

$$
\begin{aligned}
I_{t}= & \beta_{0}+\beta_{1} \cdot \mathrm{FDI}_{t}+\beta_{2} \cdot \mathrm{GDPgrowth}_{t}+ \\
& +\beta_{3} \cdot \mathrm{INF}_{t}+\beta_{4} \cdot B_{t}+\beta_{5} \cdot S_{t}+ \\
& +\beta_{6} \cdot \mathrm{RIR}+\beta_{7} \cdot I_{t-1}+\epsilon_{t},
\end{aligned}
$$

where $I$ is investment, FDI is the net inflow of foreign direct investments, GDPgrowth is the annual growth rate of the GDP per capita, INF is the inflation rate, $B$ is the public debt, RIR is the real interest rate, $S$ is the gross national savings, $t$ is the current time variable and $t-1$ is the first lag of the time variable, $\epsilon_{t}$ is the error term. Investment, FDI, public debt and saving are measured as percent of GDP, whereas GDPgrowth, inflation and the real interest rate are measured as percent.

The first phase is to filter the non-stationary variables with Augmented Dickey-Fuller test. Next, it is the correlation analysis among the variables. The third step to run OLS test with the first differential value of the determinant variables and the lagged dependent variable. Because of the limited significance, a second OLS test needs to be run which includes first differential of logarithmic values of the determinants. The logarithmic form of variables still includes unit root in the time series, that is why there is need for transformation to the first differential. The higher $R^{2}$ and better Durbin-Watson values give reason for the second OLS test. (The stationary variables were not transformed to the regression analysis.)

The data source is the Bloomberg database. The gross national savings and the investments data were indirectly imported from the IMF data base, the FDI net inflow and the annual 
GDP per capita growth ratio indirectly from World Bank database.

The annual percentage changes in savings of the analysed countries include strong comovement among the Southeast Asian countries' savings (except for Vietnam) and, due to the country's culture, a high saving rate. There are three significant negative shifts. The first between 1997 and 1998 due to the crisis in the Southeast Asia. It resulted in declining savings but not so sharply as the falling investments. This phenomenon led to imbalance between the two indicators. The second was due to the slowdown in US economy in 2001 and the third in 2008 due to the global financial crisis.

It is worth highlighting the tremendous growth in Vietnam's savings in 2005. The government launched its four-year socio-economic plan stimulating the growth of savings (Newman et al., 2006). China, like the Southeast Asian countries, has always been characterized by a high level of savings. Savings were slightly dropped back only by the Southeast Asian crisis in 1997. Since 1999 until 2007, a huge increase in savings was experienced, with an average $18.6 \%$ increase in government, corporate and household savings. The growth in private sector savings is due to the high profitability of companies. In the case of the government sector, primarily the increased tax revenues are in the background. As far as households are concerned, savings in this sector have increased the most. This is partly due to rising wages and, on the other hand, to the conscious consumer behaviour of the population (Yang et al., 2011).

The change of foreign investments was mainly affected by the economic crisis in Southeast Asia between 1995 and 2000 (except China). It is important to mention that commercial and financial liberalization programs have been introduced in Southeast Asian countries since the 1980s and these countries have had stable macroeconomic indicators (low budget deficit, stable exchange rate, high savings rate, etc.), which characteristic made the region very attractive for foreign capital (Bautista and Maveyraud-Tricoire, 2007). The Southeast Asian crisis has caused the biggest damage to investment in South Korea $(-45 \%)$, Thailand $(-32 \%)$ and Singapore $(-16 \%)$.

The long-term effects of the Southeast Asian crisis manifested in that the foreign investment started to increase in the post-crisis period but did not reach the pre-crisis volume. On the one hand, the existing excessive capacity deterred the emergence of new investments. On the other hand, investment in Southeast Asian countries was clearly risky for investors (Lee and McKibbin, 2006), mainly due to structural problems (e.g. liquidity problems of financial institutions).

In China, the average FDI growth was $10 \%$ in the 90s. The Southeast Asian crisis had weak effect, thus, the FDI inflow deteriorated only by $1 \%$ in comparison to the previous year. After a greater slowdown occurred in the 2000s, there was a large influx of FDI (except for 2008, when FDI fell because of the effects of the global financial crisis), which was induced by China's favourable regulatory system for foreign investors. A significant part of FDI is still flowing into the manufacturing sector, but in the last couple of years, the service sector showed the highest growth in FDI (Davies, 2013).

Meanwhile the FDI quickened in the analysed region, the domestic investments seemed to be crowded out as their growth slowed down in the region. The decreasing tendency can be observed in each country, which is primarily the result of the fact that foreign capital inflows crowded out the domestic capital.

\section{RESULTS}

First, Dickey-Fuller tests (ADF) were completed. According to the null hypothesis there is a unit root in the time series. Our results are shown in Tab. 1. Where there is a unit root, the time series should be differentiated or transfer into logarithmic form to make stationary and thus to be included in a regression model. Among our variables, the time series GDP 
Tab. 1: Augmented Dickey-Fuller test

\begin{tabular}{lcccc}
\hline Variable & $\begin{array}{c}\text { P-value } \\
\text { (lags) }\end{array}$ & $\begin{array}{c}\text { Stationary } \\
\text { time series }\end{array}$ & $\begin{array}{c}p \text {-value of } \\
\mathbf{1}^{\text {st }} \text { differential }\end{array}$ & $\begin{array}{c}\text { Stationary } \\
\mathbf{1}^{\text {st }} \text { differential }\end{array}$ \\
\hline Debt in \% of GDP & $0.1380(1)$ & NO & $0.0030(1)$ & YES \\
Net FDI inflow in \% of GDP & $0.2894(2)$ & NO & $0.0000(2)$ & YES \\
GDP per capita growth ratio \% & $0.0000(1)$ & YES & - & - \\
Real interest rate & $0.0016(1)$ & YES & - & - \\
Inflation & $0.0000(1)$ & YES & - & - \\
Domestic savings in \% of GDP & $0.1385(2)$ & NO & $0.0000(2)$ & YES \\
Investment in \% of GDP & $0.4949(2)$ & NO & $0.0000(2)$ & YES \\
\hline
\end{tabular}

Source: Bloomberg, IMF, World Bank.

Tab. 2: Correlation between the variables

\begin{tabular}{lrrrrrrr}
\hline & Investment & Debt & FDI & GDP growth & Inflation & $\begin{array}{c}\text { Real interest } \\
\text { rate }\end{array}$ & Saving \\
\hline Investment & 1.000000 & -0.480747 & -0.085231 & 0.574047 & 0.295034 & -0.105068 & 0.577051 \\
Debt & -0.480747 & 1.000000 & 0.091056 & -0.429747 & -0.308899 & 0.008265 & -0.318261 \\
FDI & -0.085231 & 0.091056 & 1.000000 & 0.146596 & 0.067300 & 0.132939 & 0.523608 \\
GDP growth & 0.574047 & -0.429747 & 0.146596 & 1.000000 & 0.223060 & -0.192537 & 0.493579 \\
Inflation & 0.295034 & -0.308899 & 0.067300 & 0.223060 & 1.000000 & -0.389367 & -0.035538 \\
Real interest rate & -0.105068 & 0.008265 & 0.132939 & -0.192537 & -0.389367 & 1.000000 & 0.071089 \\
Saving & 0.577051 & -0.318261 & 0.523608 & 0.493579 & -0.035538 & 0.071089 & 1.000000 \\
\hline
\end{tabular}

Source: Bloomberg, IMF, World Bank.

growth, real interest rate and inflation did not contain unit roots, so in their case there was no need for logarithmic form.

Next step, the co-movement between the variables was analysed. As it is indicated in Tab. 2, it can be deduced that there is no strong correlation between explanatory variables. After implementation of the tests, panel regression was performed. In our first regression with $1^{\text {st }}$ differentials, only the GDP growth and the $1^{\text {st }}$ differential of lagged saving proved themselves to be significant. In the first regression, the Durbin-Watson statistic is 1.8284 which value indicates the presence of positive autocorrelation (Tab. 3, Model 1). To address this, the variables were transformed to logarithmic value, but it did not exclude the presence of autocorrelation. That is why the logarithmic values were differentiated. Thus, as it appears in our second regression with $1^{\text {st }}$ differentials of logarithmic value of variables, Durbin-Watson resulted in a value above 2 , which means successful elimination of autocorrelation (Tab. 3, Model 2).
Based on the $p$-value, we observed that at $95 \%$ confidence interval the lagged dependent variable the GDP per capita growth, the FDI the current saving and the lagged saving are significantly influencing current investment. Thus, according to the model, savings have impact on investment in the countries surveyed, and the 1 year lagged saving has outstanding positive impact among the determinants. Matching to our initial expectations, the relationship between the investment and lagged domestic saving is positive. The impact of domestic savings is significant. The model contains 225 observations, so the results are robust. Based on the regression analysis, it can be stated that lagged domestic savings affect investments much more, than the inflow of foreign capital. However, we have to conclude, too, that not the current saving is important, but the lagged saving. The negative coefficient of the FDI can understood as the crowding-out impact mentioned in the literature review. 
Tab. 3: Regression with $1^{\text {st }}$ differentials of variables and $1^{\text {st }}$ differential of logarithmic value of variables at least $5 \%$ significance

\begin{tabular}{lcc}
\hline Model & $\begin{array}{c}\text { Model 1. diff } \\
1^{\text {st }} \text { diff. of investment }\end{array}$ & $\begin{array}{c}\text { Model 2. log and diff } \\
1^{\text {st }} \text { diff. of log-investment }\end{array}$ \\
Dependent variable & Coefficient & Coefficient \\
\hline Variables & $-1.942186^{* * *}$ & $-0.075097^{* * *}$ \\
\hline Constant & $0.013412^{* * *}$ & $0.013412^{* * *}$ \\
GDP growth & $0.197427^{* * *}$ & - \\
$1^{\text {st }}$ differential of lagged saving $(\mathrm{lag}=1)$ & - & $-0.393945^{* * *}$ \\
$1^{\text {st }}$ diff. Log-saving & - & $1.205534^{* * *}$ \\
$1^{\text {st }}$ diff. LogLag-saving (lag $\left.=1\right)$ & - & $-0.047769^{* * *}$ \\
$1^{\text {st }}$ diff. of Log-FDI & - & $-0.274487^{* * *}$ \\
$1^{\text {st }}$ diff. LogLag-investment $(\mathrm{lag}=1)$ & 0.266071 & 0.410256 \\
\hline$R$-squared & 1.828418 & 2.049447 \\
Durbin-Watson & 242 & 225 \\
Number of observations & - & - \\
\hline
\end{tabular}

Source: Bloomberg, IMF, World Bank (significance: $* * *$ at $1 \%, * *$ at $5 \%, *$ at $10 \%$ ).

\section{DISCUSSION}

The literature review particularly overlaps with the results of the current research in the following theses: 1) relation between savings and investment (Feldstein and Horioka, 1980; Bayoumi, 1990; Liu and $\mathrm{Xu}, 1997)$; 2) importance of savings in economic growth (Kim, 2001); 3) crowding-out effect on FDI (Tang et al., 2008; İpek and Ayvaz Kızılgöl, 2015); 4) impact of low and negative interest rates on investment (McKinnon, 1973; Show, 1973; Cho, 1990).

Our results have consonance with the Feldstein-Horioka puzzle in a special way. The OLS regressions proved, that the domestic savings are causing investments but with one period lag. As Tesar (1991) stated and Bibi and Jalil (2016) reviewed, the empirical literature of the puzzle concluded that this is a sample bias problem whether there is higher capital mobility and lower importance of domestic savings (Fidrmuc, 2003) or - contrary - because of low capital mobility, the domestic savings has measurable significance in investment (Attanasio, 2000).

Our findings about the impact of savings is that there might be a limited capital mobility in the Southeast Asian region as significance of savings was proved in our analysis. However, it looks like that the not the current savings has the positive effect but the savings lagged with one year. This can indicate a slow realization of investment from savings in the region.

Overall, the analysed group of countries demonstrates the economics intuition worded by Feldstein and Horioka (1980) or Bayoumi (1990) among others. The impact of domestic savings is significant. Since investment contributes to the GDP, it can be concluded that economics intuition whether saving has importance in economic growth, since it affects investment, has been confirmed in harmony with the existing literature.

About the crowding-out effect of savings on FDI, is significant, however, very-very small, although with negative coefficient. This can be translated as savings are important and FDI is not important in the determination of rate of investment. Even though there is a minimal crowding-out effect, it is much closer to agree with the VAR model conclusion by Tang et al. (2008) about no sign of crowding-out, and not really supporting the conclusion made by İpek and Ayvaz Kızllgöl (2015) about the existence of crowding-out.

Although some wildly used citations were collected about the unfavourable impact of 
low and negative interest rates on investment (McKinnon, 1973; Shaw, 1973; Cho, 1990), the current study did not find any negative consequences on investments originated in the interest rates of the analysed countries. The rates were definitely not in the negative margin, and maybe neither low enough. The regression analysis did indicate any significance of interest rates on investments, that is why this variable got excluded among the valid determinants.

\section{CONCLUSION}

The study analysed the relation between domestic savings and investment in the Southeast Asian region. The assumption was originated in the Feldstein-Horioka puzzle conjecturing that the domestic savings determine investment. The hypothesis is that domestic savings stimulate economic growth through investment financing and, thus, the high savings rate observed in Southeast Asian countries can contribute to the outstanding GDP growth in the region.

The literature review uncovered that one of the explanations for high economic growth in the deduces that high level of capital accumulation is the explanation of high investment activity and dynamic economic growth in Southeast Asia. In some literature it was concluded that capital accumulation was remarkable in the region, but productivity growth was rather average, thus, the remarkable performance in the region was a result of high level of savings.

The hypothesis was tested on domestic savings between 1982 and 2016 in a panel regression analysis. Singapore, Thailand, Malaysia, China, South Korea, Vietnam and Japan was included in the panel. The analysis focused on explaining variables and the co-movements. The methodology was a panel regression analysis. The following economic indicators were included as the explanatory variables in the model: real interest rate, inflation, GDP growth and government debt.

Augmented Dickey-Fuller test was implemented to uncover the unit root problem. Logarithmic form was introduced to filter the unit root out time series. Among the implemented determinants the following ones did not contain unit root: the time series of GDP growth, real interest rate and inflation. Namely, in their case there was no need for logarithmic form.

The Durbin-Watson statistic indicated autocorrelation. To eliminate it, the logarithmic and differentiated transformation of the variables was incorporated in the model. This resulted a successful elimination of autocorrelation

The purpose of analysis was achieved successfully, and the significance of domestic savings was demonstrated beside other variables, and this way the hypothesis was confirmed. Namely, the domestic savings affect investments and indirectly the economic growth. Our new finding is that the lagged savings proved itself to be important in the investment impact and not the current one. The conclusion is that national savings have the most determining impact on investments and not the FDI. Based on the regression analysis, it can be stated that domestic savings affect investments in the Southeast Asian region much more than inflow of foreign capital.

\section{ACKNOWLEDGEMENT}

The research was supported by the MKB Bank. 


\section{REFERENCES}

ASEAN and UNCTAD. 2017. ASEAN Investment Report 2017: Foreign Direct Investment and Economic Zones in ASEAN. Jakarta: ASEAN Secretariat.

Attanasio, O. P., Picci, L. and Scorcu, A. E. 2000. Saving, Growth, and Investment: a Macroeconomic Analysis Using a Panel of Countries. Review of Economics and Statistics, 82 (2), 182-211.

BĂLĂCEAnU, C. T. 2011. Keynesian Teachings: Past and Present. Cogito: Multidisciplinary Research Journal, 2, 89-97.

Bautista, C. C. and Maveyraud-Tricoire, S. 2007. Saving-Investment Relationship, Financial Crisis and Structural Changes in East Asian Countries. Economie Internationale, 111, 81-99.

Baxter, M. and Crucini, M. J. 1993. Explaining Saving-Investment Correlations. The American Economic Review, 83 (3), 416-436.

Bayoumi, T. 1990. Saving-Investment Correlations, Immobile Capital, Government Policy, or Endogenous Behavior? IMF Staff Papers, 37 (2), 360-387.

Benczes, I. 2002. A fejlesztő állam válsága Ázsiában. Külgazdaság, 46 (5), 23-40.

BibI, N. and JALIL, A. 2016. Revisiting FeldsteinHorioka Puzzle: Econometric Evidences from Common Coefficient Mean Group Model. Pakistan Economic and Social Review, 54 (2), 233-254.

Cно, Y. J. 1990. McKinnon-Shaw versus the Neostructualists on Financial Liberalization: A Conceptual Note. World Development, 18 (3), $477-480$.

Collins, S. M. and Bosworth, B. P. 1996. Economic Growth in East Asia: Accumulation versus Assimilation. Brookings Papers on Economic Activity, 2, 135-191.

Davies, K. 2013. China's Investment Policy: An Update. OECD Working Papers on International Investment, 2013/01. OECD Publishing.

Diamond, P. A. and Vartiainen, H. 2007. Behavioral Economics and Its Applications. Princeton, Oxford: Princeton University Press.

Feldstein, M. and HoriokA, C. 1980. Domestic Saving and International Capital Flows. The Economic Journal, 90 (358), 314-329.

Fidrmuc, J. 2003. The Feldstein-Horioka Puzzle and Twin Deficits in Selected Countries. Economic of Planning, 36 (2), 135-152.

Halmai, P. 2015. Structural Reforms and Growth Potential in the European Union. Public Finance Quarterly, 60 (4), 510-525.
İPeK, E. and Ayvaz KizILgöl, Ö. 2015. The Contribution of FDI Flows to Domestic Investment: An Econometric Analysis of Developing Countries. Yönetim ve Ekonomi, $22(2), 401-413$.

Kapounek, S., Koráb, P. and Deltuvaitė, V. 2016. (Ir)rational Households' Saving Behavior? An Empirical Investigation. Procedia Economics and Finance, 39, 625-633.

KIM, Y.-H. 2001. The Asian Crisis, Private Sector Saving, and Policy Implications. Journal of Asian Economics, 12 (3), 331-351.

Lee, J.-W. and McKibbin, W. J. 2006. Domestic Investment and External Imbalances in East Asia. Brookings Discussion Papers in International Economics, No. 172.

LI, C. 2010. Savings, Investment, and Capital Mobility within China. China Economic Review, 21 (1), 14-23.

LiU, J.-C. and XU, L. 1997. Household Savings and Investment: The Case of Shanghai. Journal of Asian Economics, 8 (1), 77-91.

Mankiw, N. G. 1997. Principles of Macroeconomics. Fort Worth, The Dryden Publisher.

MátyÁs, A. 1980. History of Modern Non-Marxian Economics: From Marginalist Revolution through the Keynesian Revolution to Contemporary Monetarist Counter-revolution. Budapest, Akadémiai Kiadó.

McKinnon, R. I. 1973. Money and Capital in Economic Development. Washington, DC: Brookings Institution.

Modigliani, F. 1966. The Life Cycle Hypothesis of Saving, the Demand for Wealth and the Supply of Capital. Social Research, 33 (2), 160-217.

NARAYAN, P. K. 2005. The Saving and Investment Nexus for China: Evidence from Cointegration Test. Applied Economics, 37 (17), 1979-1990.

Newman, C., Tarp, F., Van den Broeck, K., QuAng, C. T. and Khai, L. D. 2006. Household Savings in Vietnam: Insights from a 2006 Rural Household Survey. Vietnam Economic Management Review, 3 (1), 34-40.

Shaw, E. S. 1973. Financial Deepening in Economic Development. New York: Oxford University Press.

Sturm, P. H. 1983. Determinants of Saving: Theory and Evidence. OCED Economic Studies, 1, 147-196. 
Tang, S., Selvanathan, E. A. and Selvanathan, S. 2008. Foreign Direct Investment, Domestic Investment, and Economic Growth in China: A Time Series Analysis. The World Economy, 31 (10), 1292-1309.
TesAR, L. L. 1991. Savings, Investment and International Capital Flows. Journal of International Economics, 31 (1-2), 55-78.

YANG, D. T., ZhAng, J. and Zhou, S. 2011. Why are Saving Rates so High in China? IZA Discussion Paper, No. 5465

\section{AUTHOR'S ADDRESS}

Gábor Kutasi, National University of Public Service, Institute of Economics and International Economics, H-1083 Budapest, Ludovika tér 2, e-mail: kutasi.gabor@uni-nke.hu

Andrea Lörincz, Corvinus University of Budapest, Institute of World Economy, H-1093 Budapest, Fővám tér 8, e-mail: landrea19931212@gmail.com

Eszter Szabó, Corvinus University of Budapest, Institute of World Economy, H-1093 Budapest, Fővám tér 8, e-mail: eszter.szabo0716@gmail.com 